\title{
Biological productivity of the landscapes of the Republic of Tyva
}

\author{
Anna Sambuu ${ }^{1 *}$, Chultem Oyuntsetseg ${ }^{2}$, and Ayurdana Amartargal ${ }^{2}$ \\ ${ }^{1}$ Tuvan Institute for exploration of natural resources SB RAS, Russian Federation \\ ${ }^{2}$ Hovd University, 84000 Hovd, Mongolia
}

\begin{abstract}
The article considers the results of research on the biological productivity of the ecosystems of the Republic of Tuva, in particular, the dynamics of phytomass reserves, pure primary products were carried out in various landscapes of Tuva from 1996 to 2021. It was revealed that the landscape zones of Tuva differ in area, climate and biome structure, where the main producers are grass ecosystems that form $48 \%$ of the NPP, the contribution of forests reaches $46 \%$, agrocenoses $1.5 \%$, i.e. more than $90 \%$ of products are created in almost equal quantities by forest and grass biomes.
\end{abstract}

\section{Introduction}

The Republic of Tyva is located in the south of Russia, in the central part of the Asian continent. By the nature of the surface structure, the territory of Tuva is typically a mountainous country, the terrain of which is represented by high ridges separated by narrow and deep river valleys or wide intermountain basins. The mountainous and hollow relief of the republic determines within its limits a complex combination of bioclimatic conditions, the uniqueness and heterogeneity of the soil and vegetation cover.

The total area of Tuva is 168.6 thousand $\mathrm{km}^{2}$. As in other areas of the mountains of Southern Siberia, on the territory of Tuva, the vegetation cover obeys the laws of the highaltitude zone with well-defined high-mountain, mountain-forest and steppe zones [1].

Tuva belongs to the old agricultural regions, since even in ancient times (since the III century BC) its territory was inhabited by pastoral tribes, concentrated mainly in intermountain basins, river valleys, the most favorable for the development of both cattle breeding and agriculture [2]. Over the course of thousands of years, the economic impact on the vegetation cover has gradually increased in two main directions: destruction of indigenous vegetation by changing the grass stand under the influence of grazing and plowing. And since 1940 the replacement of natural ecosystems in agrocenoses leads to a change in their productivity.

\footnotetext{
* Corresponding author: $\underline{\text { sambuu@email.ru }}$
} 


\section{Materials and methods}

The productivity of the ecosystem reflects the biological potential of the system and is characterized by two parameters - the stock of phytomass and net primary production (NPP), that is, the amount of organic matter created by green plants per unit of time (month, year) per unit area $\left(\mathrm{m}^{2}\right.$, ha) [3].

To calculate the reserves of phytomass and net primary products of various ecosystems of Tuva, geobotanical maps were used, which show the boundaries of natural vegetation and generalized arrays of anthropogenic transformations $[4,5]$. Based on the maps, the areas of the main vegetation types for various landscapes of Tuva were estimated.

For the study, structuring was carried out by landscape zones, biomes and types of land use in Tuva. The following landscape zones are identified: taiga, forest-steppe, steppe, mountain landscapes and river valleys. Biomes are defined by the type of vegetation and include: forests, grass ecosystems (steppes, meadows and grass swamps), high-mountain ecosystems (scree, rocks, unclosed vegetation groups, tundra). The types of land use include: agrocenoses, hayfields and pastures, intensively exploited forests, disturbed lands burning, logging, ravines, anthropogenic agglomerates - cities, towns, roads, etc.

In the process of biota production, the quantitative expression of which is pure primary production, not only a new phytomass is created, but also carbon dioxide is consumed and oxygen is released $[6,7]$. In this regard, the reserves of phytomass, mortmass and the value of products estimated for the territory of Tuva characterize its biopotential.

\section{Results and discussions}

The mountainous appearance of the republic determines its phytomass and the distribution of the latter among biomes. High-mountain landscapes, including mountain tundra, glaciers, and unclosed plant groupings, make up $23 \%$ of the territory of the republic. All these ecosystems have low phytomass and products. Their contribution to phytomass is $3.5 \%$, to mortmass is much more $-16 \%$ and to products $-6 \%$.

The main biome of the republic by area is forests, the areas of which occupy $49 \%$ of the republic's area. Agroecosystems are smaller than grass ecosystems, man-made and residential landscapes are in the last place, occupying only $2 \%$ of the republic's area.

The forest vegetation of Tuva is confined to the mountain elevations and consists mainly of Larix sibirica Ledeb. and Pinus sibirica Du Tour., which occupy 47.1 and $44.7 \%$ of the forest area [8]. The total wood reserves are estimated at 1090.85 million $\mathrm{m}^{3}$, of which Larix sibirica accounts for $51.8 \%$ and Pinus sibirica $-43.1 \%$. Forest lands form $95 \%$ of the phytomass and $72 \%$ of the mortmass. The share of forests in the composition of products is significantly less - only $46 \%$.

Grass ecosystems occupy $20 \%$ of the territory of the republic - steppes, meadows in hollows, subalpine and Alpine meadows in the mountains, where the phytomass density of grass ecosystems reaches $4.1 \mathrm{t} / \mathrm{ha}$, which is due to the high stock of living subsurface plant organs of meadow and real steppes and subalpine meadows. The low density of phytomass is due to the fact that the main type of untilled grass ecosystems in Tuva are dry and desolate steppes, the phytomass of which is significantly lower than the phytomass of meadow steppes. The density of the mortmass of grass ecosystems is high $-5.5 \mathrm{t} / \mathrm{ha}$ due to the deposition of a large number of dead undecayed roots and rhizomes in the soil. The production of grass ecosystems is also high, accounting for $48 \%$ of the NPP of the vegetation cover of the republic.

The area of agrocenoses is very small $(1.5 \%)$, which explains the extremely low contribution of this biome to phytomass and products. The phytomass of agrocenoses is mainly formed by grain and fodder crops, industrial crops and vegetables occupy a small 
area. The reserves of mortmass are 0.8 times lower than the reserves of phytomass. The contribution of forests to the mort mass is lower, and the contribution of grass ecosystems is higher than in the phytomass. The Republic of Tyva is a mountainous forest country, where the forest determines the potential of biota reproduction.

Thus, the landscape zones of Tuva differ in area, climate and biome structure. Out of 16,800 thousand hectares of the total area of the republic, 8278 thousand hectares are forest, 1355 forest - steppe and 3298 steppe zones [8, 9]. Therefore, they differ in the values of both phytomass and products, and these indicators do not correlate with the area of the zones.

The absence of a direct proportional relationship between the area on the one hand, phytomass and products on the other hand is due to the different biome structure of the zones. The largest reserves of phytomass are primarily determined by the area of forests of the republic, which is covered with indigenous conifers with Larix sibirica, Pinus sibirica, Pinus silvestris L. and Picea obovata L. (93.8\%) and small-leaved forests, in which agrocenoses and pastures are interspersed with small spots. The main type of transformation is characterized by a small area of intensively exploited plantings, cuttings and harems, and occupied by anthropogenic agglomerates - mineral development, industrial facilities, cities, towns, roads, etc.

Different tree species have different time of wood reproduction: Pinus sibirica - more than 70, Larix sibirica - about 60, Pinus silvestris - from 40 to 50 and Betula pendula Roth. - from 20 to 40 years depending on the growing conditions [10]. Larch and pinebirch forests and forest-steppes of Tuva are reproduced much faster.

The value of production is also not related to the total area of zones and depends on the area of grass ecosystems, which are characterized by high production among existing ecosystems. The main producers are grass ecosystems, which form $48 \%$ of the NPP, the contribution of forests reaches $46 \%$, agrocenoses $1.5 \%$.

The high production of grass ecosystems is the reason for the reproduction of their biomass in one year or less. The latter means that more phytomass grows and dies in one year than it is contained on average per unit area. The time of re-production is stretched over the entire growing season: in the spring, the types of spring vegetation increase, they are replaced by types of summer vegetation, part of the phytomass of which dies in the second half of summer, in the autumn, late-summer species vegetate and early-summer and summer ones die. As a result, the amount of phytomass grown during the season is higher than its "standing on the root" amount in the middle of summer. A similar situation develops in agrocenoses: before harvesting, at the time of which the phytomass is estimated, part of the leaves, whole plants, roots have already died and are not included in the phytomass.

\section{Conclusion}

So, the higher the participation of forests in the vegetation cover of the republic, the higher the phytomass and the long time of reproduction of biota, the higher the participation of grass ecosystems, the higher the production and the shorter the reproduction time.

The reported study was funded by RFBR according to the research project № 19-2905208/19 mk and partly within the framework of the State assignment of the Tuvan Institute for exploration of natural resources SB RAS № 0307-2021-0003. 


\section{References}

1. A. D. Sambuu, I. M. Krasnoborov, V. V. Sevastyanov, M. G. Sevastyanova, M. G. Sukhova, M. F. Andreychik, V. I. Kudryavtsev, A. I. Kudryavtseva, V. I. Zabelin, T. P. Archimaeva, S. S. Kurbatskaya, E. A. Gurkova, T. N. Prudnikova, V. V. Zaika, L. K. Arakchaa, A. N. Kuksin, D. K. Kuksina, Natural Resources of the Republic of Tyva (Novosibirsk, Garamond Publishing House, 2018)

2. History of Tuva, Vol. 1. (Novosibirsk, Nauka, 2001)

3. A. A. Titlyanova, Biological carbon cycle in grass biogeocenoses (Novosibirsk, Nauka, 1977)

4. A. I. Schroeter, Natural conditions of the Tuva Autonomous region (Moscow, Publishing House of the USSR Academy of Sciences, 1957)

5. A. V. Kuminova, V. P. Sedelnikov, Yu. M. Maskaev, et al., Vegetation cover and natural feeding grounds of the Tuva ASSR (Novosibirsk, Nauka, 1985)

6. N. I. Bazilevich, Biological productivity of ecosystems of Northern Eurasia (Moscow, Nauka, 1993)

7. A. A Titlyanova, S. Ya. Kudryashovф, N. P. Kosykh, S. V. Shibareva, Natural resources of the anthroposphere: reproduction, costent (Moscow: Yanus-K, 2002)

8. K. O. Shaktarzhik, Forest and land resources of the Republic of Tuva (Kyzyl, TuvIENR SB RAS, 2000)

9. A. V. Kuminova, V. P. Sedelnikov, Yu. M. Maskaev, et al., Vegetation cover and natural feeding grounds of the Tuva ASSR (Novosibirsk, Nauka, 1985)

10. V. A. Sokolov, Fundamentals of forest management in Siberia (Krasnoyarsk, Publishing House of SB RAS, 1997) 